\title{
Impact of Political Connection on Farming Households' Performance of Tea Production in Vietnam
}

\author{
Nguyen To-The ${ }^{1,2} \&$ Quoc Tran-Nam ${ }^{1,3}$ \\ ${ }^{1}$ BETA, University of Strasbourg, Strasbourg, France \\ ${ }^{2}$ Vietnam National University of Agriculture, Hanoi, Vietnam \\ ${ }^{3}$ Saigon University, Ho Chi Minh City, Vietnam \\ Correspondence: Nguyen To-The, BETA, University of Strasbourg, 61 Avenue de la Foret Noire, F-67000 \\ Strasbourg, France. E-mail: tothenguyen@gmail.com
}

Received: September 8, 2015 Accepted: October 25, 2015 Online Published: November 15, 2015

doi:10.5539/jas.v7n12p107 URL: http://dx.doi.org/10.5539/jas.v7n12p107

\begin{abstract}
Purpose: This paper aims to investigate the impacts of political connections on farming households' performance, especially in tea production.

Methodology/Approach: The Box-Cox methodology is applied using the primary data surveyed on 244 tea farming households in Vietnam.

Findings: The findings show the significant role of political connection on improving farming households' income, particularly to members of the Communist Party, Youth Union and Farmer's Union. However, the interaction effects of Farmer's Union, Youth Union, Veteran's Union and Communist Party with land has negatively significant impact on farming household income.

Practical Implications: The evidences point out the capacity of improving tea producers' income could be really potential implying most of existing related policies which should be adjusted.

Originality/Value: This is the first research examining the impact of political connection on agricultural performance, especially in tea production. The impacts are estimated in de-tail; such as participating more on Veteran's, Farmer's, Youth Union and Communist Party may reduce time on cultivating; as a result, cultivated land could be reduced. Basing on these findings, we also suggest some appropriate policy implications related to the issue how to improve income of tea production households.
\end{abstract}

Keywords: political connection, Box-Cox, households' performance, tea production

JEL Classi Cation: G32, C1; C21, Q12

\section{Introduction}

Research on the political connection is really abundant in economic literature. Some authors emphasized the relationship between political connection and economic growth (e.g., Bardhan \& Mookherjee, 2000; Ferraz \& Finan, 2008). In addition, connections between firms and politicians have been extensively widespread in recent years. Several recent studies indicate that a significant part of a firm's value comes from political links that could increase the firm value (Fisman, 2001; Faccio et al., 2006; Claessens et al., 2008). Politically connected firms may also receive advantages from governments' decisions such as the awarding of licenses, government contracts, bailouts for distressed firms (Fisman, 2001; Khwaja \& Mian, 2005; Faccio et al., 2006; Charumilind \& Wiwattanakantang, 2006; Leuz \& Oberholzer-Gee, 2006; Firth et al., 2011).

Furthermore, the literature has also identified the value of political connections in corrup-tive countries (e.g., Fisman, 2001; Li et al., 2008; Bunkanwanicha \& Wiwattanakantang, 2009; Cingano \& Pinotti, 2013; Goldman et al., 2009). Certain studies estimated the market value of political connections (e.g., Fisman, 2001; Faccio et al., 2006). However, examining the relationship between political connection and household income, especially in agriculture is still scarce. Our research aims to fill this gap by investigating the role of political connection on farmers' performance in Vietnam.

Before proceeding, we first discuss the concept of "political connection". Generally, political connection has 
always been defined in a inconsistent and non-obvious way. In fact, Faccio (2006) suggested the definition that a firm considered having a political connection if one of its large shareholders or top officers is: (i) A member of parliament, (ii) A minister or the head of state, or (iii) Closely related to top officials. Similarly, Faccio et al. (2006) also defined that a firm could be politically connected if at least one type leaders (chief executive officer, chairman of the board, president, vice-president, or secretary of the board or a large shareholder) becomes a head of state (i.e., president, king, prime minister, a government minister or a member of the national parliament). However, on another aspect, Firth et al. (2011) supposed that a political connection would be formed when at least one of the board members, top managers, or major stockholders has a relationship with someone in the government. The important role of informal connections between government officials and private agents were also mentioned. In addition, Dalton et al. (2002) also examined the patterns of social relations and social capital. They used variables such as family, friend, work, religious, education, age, gender and income, but they only compared the interaction between these variables by a simple method.

Theoretically, formulating a consistent definition of political connection seems to be impossible because it depends on several social and cultural backgrounds in a specific country or even in a region. For instance, in Vietnam, there are some organizations such as Farmers' Union, Youth Union, Communist Party, Women' Union and Veteran's Union, etc. Because they are considered as the solid components forming the communist party, the unique political party in Vietnam. As a result, they have strong links with the state and their membership could help getting advantages in business, job search, education, promotion, etc. Therefore, in this research, we define that a household will be considered as having a political connection if one or more members of the household is involved into these organizations. However, a member of an organization is not necessary always joining Communist Party or others at the same time. Our data set contains information about these households. We will investigate the effects of these variables on household income in Vietnam.

To estimate this relationship, we use primary data surveying tea farming households in three provinces in Vietnam and apply a Box-Cox regression. We find an interesting result that the relationship between political connection and household income is not clear. The other finding shows that households without political ties could not obtain as much information as the well connected households. This is likely to imply a certain significant impact of political link on economic performance.

The chapter is organized as follows. Section 2 discusses the role of political connection on firms and households a discussion which is based on previous researches. Section 3 presents the estimation method and describes the data we collected ourselves in Vietnam. Empirical findings will be analyzed in Section 4. Finally, Section 5 will give some conclusion and suggest some policy implications.

\section{Literature Review on the Role of Political Connection on Firms and Household Performance}

Studies on political connection are numerous. Studying firms in Malaysia, Adhikari et al. (2006) examined the relation between political link and effective tax rates. They found that political connection can cause a negative effect on tax rate. Independent variables include proxies for political connections, firm size, capital structure, asset mix, firm performance, growth prospects. Charumilind and Wiwattanakantang (2006) investigated the influence of political ties on firm's loans in Thailand and pointed out that firms having a political connection could have more long-term loans although less collateral. Faccio et al. (2006) analyzed the government bailouts of 450 political connected firms from 35 countries over period 1997-2002. The results illustrated that politically connected firms have much more opportunities to be bailed out when facing complications than unconnected firms. They also found that political ties in countries with high levels of corruption generating a statistically significant cumulative abnormal return (CAR) of $4.32 \%$, versus an insignificant CAR of $0.02 \%$ in countries with low levels of corruption. Besides, Leuz and Oberholzer-Gee (2006) used a data set of 130 Indonesia firms to explore the role of political relationships in firm's financing. The paper applied a probit model to estimate effects of independent variables including Closeness to Suharto (President Suharto), Suharto family owned, state-owned enterprise, firm size, ratio of operating income to total assets, capital intensity, financial leverage and industry including agriculture, manufacturing, transports, trade and finance. They indicated the interesting evidence that strongly politically connected firms are less likely to have publicly traded foreign securities.

In a more recent work, $\mathrm{Li}$ et al. (2008) examined, for private firms in China, the role of association with Communist Party for business activities. By estimating the profitability and using return on assets and on equity as the dependent variables. The research pointed out that party membership and education variables have a significantly positive effect on dependent variables. However, management experience, former public firm manager, former cadre, PC (People's Congress) membership, CPPCC (Chinese People's Political Consultative Con-ference) membership are not significant statistically. Niessen and Ruenzi (2010) investigated politically 
connected firms in Germany. The result showed that firms with political ties are less risky, however, the market value is lower than firms without political connection. They also specified that politically connected firms provide better stock market performance. Fur-thermore, politically connected firms have significantly higher returns on equity and returns on investments. Boubakri et al. (2012) found that firms with political link have a lower cost of equity and are generally considered as less risky than non-connected firms.

Analyzing Chinese firms during 1999-2006, Wu et al. (2012) found that private politically connected firms have a higher value and obtain more government subsidies than others. Meanwhile, local state-owned firms have a lower value. Similarly, Amore and Bennedsen (2013) gave evidence of Danish firms being able to increase significantly their performance when they have a connection with local politicians. Contrarily, concerning Italian firms over period 1985-1997, Cingano and Pinotti (2013) found that political connection may entail significant economic losses.

Some authors pay attention to the role of political connection on stock market. Faccio (2006) examined the relationship between publicly traded firms and politically linked in 47 countries and showed the existence of this relationship in 35 countries. This study also showed that national political ties are valuable, especially in countries having weak political institutions. Fan et al. (2007) released empirical evidence of the negative relationship between politically connected of chief executive officer and the first day stock return. That could be interpreted as a signal of government intervention. In addition, Goldman et al. (2009) explored the effects of political connection on stock market in the United States. They used a data set of board members of 500 companies connected to the Republican Party and the Democratic Party for the 2000 presidential election. As a result, the stock value of companies connected to the Republican Party increased and, on the contrary, the stock value of companies connected to the Democratic Party decreased.

Moreover, Caeyers and Dercon (2012) examined the role of political connections in the allocation of food aid in rural Ethiopia, applying a probit model. They used variables including the number of persons in the household relying on in times of need, per capita real consumption, average work ability score of the household head, land area owned per capita, household size have a significantly negative effects to allocation of food. Variables such as household have closed associates holding official position; households receiving free food in the past have significantly positive effects to allocation of food. The research also found strong evidence of politically connected and favoritism; for instance, it indicated that a well-connected house-hold had a $10 \%$ higher probability to obtain free food than the unwell-connected households. In addition, few studies mentioned the relation between political link and household income. Recently, Markussen and Tarp (2014) explored the effects of political power on farmers' agricultural investment decisions and a significant increase in land-investment of household when their relatives are working into public sector. The authors also mentioned the relation be-tween political connections and property rights, using of credit, worker wage. Furthermore, it indicated that if unwell-political connected farmers could obtain equal property rights and access to credit as well as the well-political connected ones.

\section{Econometric Modeling and Data}

\subsection{Econometric Modeling}

In this research, to deal with the dropping issue, we will apply the Box-Cox model to estimate the role of political connection factors on tea producers' income in Vietnam (Note 1). We reply to the works of Wooldridge (1992), Sakia (1992) and Abrevaya (2002) (Note 2). We assume that household income is a function of political connection and other explanatory variables.

We use maximum likelihood to obtain estimates of the parameters for the Box-Cox model. The most general Box-Cox model is,

$$
y_{i}^{(\theta)}=\beta_{0}+\beta_{1} x_{1 i}^{(\lambda)}+\beta_{2} x_{2 i}^{(\lambda)}+\ldots+\beta_{K} x_{K i}^{(\lambda)}+\gamma_{1} z_{1 i}+\gamma_{2} z_{2 i}+\ldots+\gamma_{h} z_{h i}+\epsilon_{i}
$$

Where, $\epsilon N\left(0 ; \sigma^{2}\right)$. Each of the independent variable, $x_{1}, x_{2}, \ldots x_{K}$, has a Box-Cox transform with the parameter $\lambda$. The $z_{1}, z_{2}, \ldots z_{h}$ are explanatory variables that are not transformed. In this model, the Box-Cox transform of the dependent variable $y$ with the parameter $\theta$. Hence, the Box-Cox transform for all variables in the model is,

$$
\omega^{(\gamma)}=\left\{\begin{array}{lll}
\omega-1 & \text { if } & \gamma=1 \\
\ln (\omega) & \text { if } & \gamma=0 \\
(\omega-1) / \omega & \text { if } & \gamma=-1
\end{array}\right.
$$

Where, $\omega=y, x_{i}$ and $\gamma=\theta, \lambda$. The log-linear model is supported if $\hat{\theta}$ is close to 0 , and the linear model is supported if $\hat{\theta}=1$. 
Basing on the works of Poirier (1978), Amemiya and Powell (1981), Spitzer (1982), Seaks and Layson (1983) and Davidson and MacKinnon (1985), the log-likelihood of this model is,

$$
\ln L=\left\{\frac{-n}{2}\right\}\left\{\ln (2 \pi)+\ln \left(\sigma^{2}\right)\right\}+(\theta-1) \sum_{i=1}^{n} \ln \left(y_{i}\right)-\left\{\frac{1}{2 \sigma^{2}}\right\} \epsilon_{i}^{2}
$$

Where, $\epsilon_{i}$ is implicitly defined as a function of $y_{i}$ by (1), and $n$ is the number of observations.

\subsection{Data Description}

The data are obtained from a cross-sectional survey of households in three provinces of Vietnam, namely Tuyen-Quang, Phu-Tho and Thai-Nguyen which is considered as one of the mainly tea production regions in Vietnam.

The survey has been randomly with households in 10 different villages. It consisted of a quantitative household survey of 244 tea farmers. The households are interviewed directly concerning information on tea production in 2012. The average duration for the whole questionnaire has been 1 hour and 13 minutes.

A definition of variables is given in the Appendix 1. The summary statistics of the variables are reported in Table 1. In this chapter, total income and tea income are measured in million VND and tea land is measured in square meters $\left(\mathrm{m}^{2}\right)$. We observe that the average total income of household is about 128.9 million VND per year, with a standard deviation of 112.9, and the rank of total income between about 8.67 and 1287.1 million VND which indicates a large variability in total income among the tea producers. Meanwhile, average tea income is approximately 65.6 million VND per farming household, with a standard deviation of 66.7, and the rank of tea income between about 2.4 and 403 million VND, which also shows a large variability. Average land surface for tea is about $5866 \mathrm{~m}^{2}$ per farming household. The mean quantity of labor participating in tea production (planting, harvesting, cultivating, etc.) is about 225 person-days.

Table 1. Summary statistics of the characteristic for the tea producers

\begin{tabular}{llllll}
\hline Variable & Mean & Std. Dev. & Min. & Max. & Obs. \\
\hline Total income & 128.94 & 112.96 & 8.76 & 1287.1 & 244 \\
Tea income & 65.67 & 66.70 & 2.4 & 403 & 244 \\
Tea land $\left(\mathrm{m}^{2}\right)$ & 5866.47 & 5997.24 & 130 & 45000 & 241 \\
Labor (person-days) & 224.63 & 542.59 & 5 & 7863 & 244 \\
Household size & 4.299 & 1.188 & 1 & 10 & 244 \\
Children & 1.119 & 0.988 & 0 & 4 & 244 \\
Elderly & 0.299 & 0.592 & 0 & 2 & 244 \\
Experience & 29.893 & 13.855 & 2 & 64 & 244 \\
Education & 3.266 & 0.702 & 1 & 6 & 244 \\
Gender & 1.430 & 0.496 & 1 & 2 & 244 \\
\hline
\end{tabular}

The average household size is 4.299 , with a standard deviation of 1.188 , and the rank of people between about 1 and 10 which indicates the large variability in member among the tea producers. Children is the number of household's members less than 18 year old. This variable is 1.119 on average, with a standard deviation of 0.988 . The average of elderly, who are more than 60 year old, is just 0.299 per household. Meanwhile, there is a large variability in experience between households. The research also includes dummies corresponding to household characteristics like gender ( $=1$ if household head is male, and $=0$ if household head is female).

The data set contains information about whether household's members are public officials (or members in associations such as Communist Party, Youth Union, Veteran's Union and Farmer's Union). These mass organizations are under strict control of Communist Party; their members, however, are not always involved in the Communist Party. 
Table 2. Data distribution following political connections

\begin{tabular}{llllll}
\hline Organizations & \multicolumn{3}{c}{ Freq. } & & \multicolumn{2}{c}{ Percent } \\
\cline { 6 - 6 } \cline { 5 - 6 } \cline { 5 - 6 } Mo: 0 & Yes: 1 & & No: 0 & Yes: 1 \\
\hline Member of Communist Party & 194 & 50 & & 79.51 & 20.49 \\
Member of Youth Union & 121 & 123 & & 49.59 & 50.41 \\
Member of Veteran's Union & 103 & 141 & & 42.21 & 57.79 \\
\hline
\end{tabular}

Table 2 gives the distribution of the data following different types of political connection which is a dummy variable, coded one if the farmer is politically connected. We define dummies corresponding to household characteristics like membership of Communist Party, Youth Union, Farmer's Union and Veteran's Union. The number of households having at least a member participating into Communist party, Youth Union, Farmer's Union and Veteran's Union are 50,123,141, and 164, respectively. These dummy variables help to investigate impact of political connection on farming household performance specifically. In addition, we also test how age, education level and experience of the household-heads affect to household total and tea income.

\section{Estimation Results}

In this section, we use tea income and total income variables as the dependent explanatory variables include agricultural land, labor, household size, elderly, children, experience, household head's education and gender.

Applying the Box-Cox model, we test the null hypothesis $H_{0}: \theta=\gamma=0, H_{0}: \theta=\gamma=1$ and $H_{0}: \theta=\gamma=-1$. The null hypothesis of $\theta=\gamma=1$ and $\theta=\gamma=0$ are then strongly rejected leading to rejections of the multiplicative inverse and log-linear models (Table 3).

Our estimation shows that land tea, labor, member of household, household head's education, household head's experience and gender variables are statistically significant. The results indicate the significant impacts of these variables on household's performance. This finding suggests a relation between total income and these factors. The significantly positive sign of the coefficient of land tea shows a positive effect of this variable on total income of household. The finding is in contradiction to Nguyen et al. (2011). Meanwhile, other variables such as labor, household size and household head's education give positively effects to total household's income, except gender. It implies that income could be improved by increasing labor, expanding land farming, and extending education. Household size is also has a positive effect on total income of household. This result is consistent with those of Leuz and Oberholzer-Gee (2006), Chen et al. (2009) and Wu et al. (2012). However, it is inconsistent with Nguyen et al. (2011). In addition, a significantly negative effect of gender on total income implies an important role of gender of household's head on total income of household. Intuitively, as tea producer is a very hard work, a male household's head does physically support it better than a female household's head. 
Table 3. Determinants of variables of income of tea producer

\begin{tabular}{|c|c|c|c|c|}
\hline \multirow{2}{*}{ Variable } & \multicolumn{2}{|c|}{ Total income (Model-A) } & \multicolumn{2}{|c|}{ Tea income (Model-B) } \\
\hline & Coef. & Chi2(df) & Coef. & Chi2(df) \\
\hline Intercept & 0.754 & 0.000 & -3.131 & 0.000 \\
\hline Land & 0.236 & 19.211 & 0.686 & 50.852 \\
\hline Labor & 0.133 & 6.612 & 0.543 & 42.942 \\
\hline Household size & 0.105 & 3.673 & -0.010 & 0.029 \\
\hline Children & -0.013 & 0.044 & 0.033 & 0.234 \\
\hline Elderly & 0.105 & 1.029 & -0.154 & 1.886 \\
\hline Experience & 0.008 & 2.713 & 0.012 & 5.718 \\
\hline Education & 0.270 & 11.010 & 0.170 & 3.788 \\
\hline Gender & -0.270 & 5.128 & -0.265 & 4.200 \\
\hline Test H0: & \multicolumn{2}{|c|}{ log likelihood } & \multicolumn{2}{|c|}{ log likelihood } \\
\hline$\theta=\lambda=-1$ & -261.03 & 91.21 & -403.78 & 256.63 \\
\hline$\theta=\lambda=0$ & -228.12 & 25.39 & -306.01 & 61.09 \\
\hline$\theta=\lambda=1$ & -215.80 & 0.75 & -275.90 & 0.88 \\
\hline
\end{tabular}

Notes. $*$ and $* *$ mean for significance at the $10 \%$ and at the $5 \%$ level, respectively.

Similarly, the results in Table 3, shows that the important role of households' head; in fact, they can make significantly positive impact on performance. In addition, land tea, labor, household head's education, household head's experience variables give statistically significant positive effects on tea income. The coefficients of education are significantly positive in both models showing increasingly effect of extending education on income. This result is also consistent with the findings of Li et al. (2008). Furthermore, experience of households' head also give positive influence on income, that is consistent with significantly positive. This is consistent with Cingano and Pinotti (2013). However, interestingly, households' female-head might have lower performance contribution in terms of income compared to male ones.

As discussed above, Box and Cox (1964) also argued that the transformation could make the residuals more closely normal and less heteroscedastic. Furthermore, this method may help to avoid the dropping of observable independent variables. Therefore, Box Cox model is applied to farmer households' performance, in which tea land is interacted with different political connections. Similarly, we also test the null hypothesis $H_{0}: \theta=\gamma=0, H_{0}$ : $\theta=\gamma=1$ and $H_{0}: \theta=\gamma=-1$. The result of computed value of the statistic show that the null hypothesis of $\theta=\gamma=$ 1 and $\theta=\gamma=0$ are then strongly rejected leading to rejections of the multiplicative inverse and linear model in two Tables 5 and 7. 
Table 4. Relationship between political ties and total income of household

\begin{tabular}{|c|c|c|c|c|}
\hline Variable & Model A1 & Model A2 & Model A3 & Model A4 \\
\hline \multirow[t]{2}{*}{ Intercept } & 0.436 & -0.547 & 0.832 & 0.507 \\
\hline & $(0.000)$ & $(0.000)$ & $(0.000)$ & $(0.000)$ \\
\hline \multirow[t]{2}{*}{ Land } & 0.231 & 0.525 & 0.246 & 0.238 \\
\hline & (13.977) & $(22.322)$ & $(17.594)$ & $(21.851)$ \\
\hline \multirow[t]{2}{*}{ Labor } & 0.099 & 0.184 & 0.134 & 0.093 \\
\hline & (6.639) & $(6.822)$ & $(6.272)$ & $(5.225)$ \\
\hline \multirow[t]{2}{*}{ Household size } & 0.105 & 0.099 & 0.108 & 0.080 \\
\hline & $(3.141)$ & (3.524) & (3.854) & $(2.480)$ \\
\hline \multirow[t]{2}{*}{ Children } & -0.024 & -0.020 & -0.018 & 0.008 \\
\hline & $(0.118)$ & $(0.115)$ & $(0.080)$ & $(0.022)$ \\
\hline \multirow[t]{2}{*}{ Elderly } & 0.142 & 0.086 & 0.107 & 0.108 \\
\hline & $(1.597)$ & $(0.735)$ & $(1.808)$ & $(1.274)$ \\
\hline \multirow[t]{2}{*}{ Experience } & 0.009 & 0.008 & 0.007 & 0.007 \\
\hline & $(2.975)$ & (2.971) & $(2.620)$ & $(2.888)$ \\
\hline \multirow[t]{2}{*}{ Education } & 0.281 & 0.266 & 0.273 & 0.236 \\
\hline & $(10.054)$ & (11.388) & (11.224) & (9.916) \\
\hline \multirow[t]{2}{*}{ Gender } & -0.227 & -0.265 & -0.270 & -0.237 \\
\hline & $(2.747)$ & $(5.341)$ & (5.129) & $(4.660)$ \\
\hline \multirow[t]{2}{*}{ Veteran's Union } & 1.297 & & & \\
\hline & (1.464) & & & \\
\hline \multirow[t]{2}{*}{ Veteran's Union Land } & -0.180 & & & \\
\hline & $(2.004)$ & & & \\
\hline \multirow[t]{2}{*}{ Farmer's Union } & & 1.969 & & \\
\hline & & $(4.989)$ & & \\
\hline \multirow[t]{2}{*}{ Farmer's Union Land } & & -0.231 & & \\
\hline & & $(4.803)$ & & \\
\hline \multirow[t]{2}{*}{ Communist Party } & & & 0.002 & \\
\hline & & & $(0.000)$ & \\
\hline \multirow[t]{2}{*}{ Communist Party Land } & & & -0.008 & \\
\hline & & & $(0.003)$ & \\
\hline \multirow[t]{2}{*}{ Youth Union } & & & & 1.522 \\
\hline & & & & $(3.560)$ \\
\hline \multirow[t]{2}{*}{ Youth Union Land } & & & & -0.162 \\
\hline & & & & $(2.801)$ \\
\hline
\end{tabular}

Notes. ${ }^{*}$ and ${ }^{* *}$ mean for significance at the $10 \%$ and at the $5 \%$ level, respectively. $t$ statistics in parentheses, $\mathrm{n}=$ 240. 
Table 5. Restricted log likelihood

\begin{tabular}{lllll}
\hline Variable & Model A1 & Model A2 & Model A3 & Model A4 \\
\hline H0: $\theta=\lambda=-1$ & -259.09 & -257.98 & -260.74 & -256.32 \\
H0: $\theta=\lambda=0$ & 92.74 & 90.13 & 90.87 & 87.74 \\
& -226.21 & -225.13 & -227.92 & -224.15 \\
H0: $\theta=\lambda=1$ & 26.98 & 24.43 & 25.23 & 23.42 \\
& -213.29 & -213.25 & -215.68 & -212.68 \\
\hline
\end{tabular}

Notes. ${ }^{*}$ and $* *$ mean for significance at the $10 \%$ and at the $5 \%$ level, respectively.

Now we turn to estimate the effect of having relative's political connection on total house-hold income. Table 4 shows that the interaction effects between tea land, labor and household income become consistent. Moreover, the role of tea land and labor become more important when they are interacted with other political connection variables. The other factors associated with political connection also give stronger effects on household performance.

Almost the coefficients of these factors are statistically significant and positive. Further-more, heterogeneity could be appeared between political connection variables. The empirical results indicate that the relationship between political connection and household income is significantly positive. However, only two proxies of political connection, member of the Farmer's Union and Youth Union, are statistically significant.

As shown in Model A2 of Table 4 points out that an increase 1\% in land and labor could lead to an increase appropriately $0.525 \%$ and $0.184 \%$ in farming household total income, respectively. The coefficient of the interaction between tea land and Farmer's Union has a significantly negative effect $(-0.231)$, representing a substitution between these two factors, that means membership of a Farmer's Union of households may substitute a decrease use the land tea. Meanwhile, the interaction effects show that the relation between membership of Farmer's Union and total income of household is positive (1.969); this implies membership of Farmer's Union may help to increase households' performance. This finding is consistent the results of other studies (Markussen \& Tarp, 2014). This finding seems to contradict with Cingano and Pinotti (2013), who confirmed that access to political connections increases firm revenues by almost $6 \%$, yielding an equivalent change in profits.

Model A4 in Table 4 point out that an increase 1\% in land and labor could lead to an increase appropriately $0.238 \%$ and $0.093 \%$ in farming household total income, respectively. Moreover, the correlation between tea land and Youth Union has a significantly negative effect $(-0.162)$, representing a substitution between two factors. Simultaneously, the interaction relation between membership Youth Union and total income is positive (1.522) implying households' income could be improved by participating to Youth Union.

Besides, we also examine the impact of political connection on tea income. The results in Table 6 illustrate the positive impact of political connection on household income tea. The coefficient effects are positive and significant strongly at the 5\% and 10\% level. Meanwhile, only two political connection variables, Veteran's Union and Communist Party, are significant statistically.

More specifically, as shown in Model B1, an increase of $1 \%$ in land and labor could lead to an increase around $0.819 \%$ and $0.502 \%$ in farming household tea income, in that order. Surprisingly, the interaction between tea land and Veteran's Union has is significantly negative effect $(-0.243)$, representing a substitution between these two factors. The negative coefficients on these interaction terms mean that Veteran's Union membership becomes less valuable corresponding to the increase of volume of tea land regarding household's income. 
Table 6. Relationship between political ties and tea income of household

\begin{tabular}{|c|c|c|c|c|}
\hline Variable & Model B1 & Model B2 & Model B3 & Model B4 \\
\hline \multirow[t]{2}{*}{ Intercept } & -4.229 & -3.779 & -3.827 & -2.707 \\
\hline & $(0.000)$ & $(0.000)$ & $(0.000)$ & $(0.000)$ \\
\hline \multirow[t]{2}{*}{ Land } & 0.819 & 0.843 & 0.848 & 0.592 \\
\hline & $(32.494)$ & $(31.687)$ & $(53.836)$ & $(27.833)$ \\
\hline \multirow[t]{2}{*}{ Labor } & 0.502 & 0.610 & 0.601 & 0.513 \\
\hline & $(43.246)$ & $(44.301)$ & $(41.764)$ & $(41.636)$ \\
\hline \multirow[t]{2}{*}{ Household size } & -0.016 & -0.007 & 0.003 & -0.018 \\
\hline & $(0.074)$ & $(0.017)$ & $(0.003)$ & 0.097 \\
\hline \multirow[t]{2}{*}{ Children } & 0.027 & 0.028 & 0.018 & 0.037 \\
\hline & $(0.143)$ & $(0.167)$ & $(0.066)$ & $(0.286)$ \\
\hline \multirow[t]{2}{*}{ Elderly } & -0.129 & -0.149 & -0.147 & -0.134 \\
\hline & $(1.233)$ & (1.684) & $(1.579$ & $(1.403)$ \\
\hline \multirow[t]{2}{*}{ Experience } & 0.013 & 0.014 & 0.130 & 0.012 \\
\hline & $(5.678)$ & $(7.148)$ & $(5.838)$ & $(5.669)$ \\
\hline \multirow[t]{2}{*}{ Education } & 0.168 & 0.190 & 0.196 & 0.169 \\
\hline & $(3.426)$ & $(4.533)$ & $(4.617)$ & $(3.743)$ \\
\hline \multirow[t]{2}{*}{ Gender } & -0.231 & -0.282 & -0.303 & -0.253 \\
\hline & $(2.655)$ & (4.612) & $(5.055)$ & $(3.837)$ \\
\hline \multirow[t]{2}{*}{ Veteran's Union } & 1.798 & & & \\
\hline & $(2.711)$ & & & \\
\hline \multirow[t]{2}{*}{ Veteran's Union Land } & -0.234 & & & \\
\hline & $(3.243)$ & & & \\
\hline \multirow[t]{2}{*}{ Farmer's Union } & & 0.843 & & \\
\hline & & $(0.686)$ & & \\
\hline \multirow[t]{2}{*}{ Farmer's Union Land } & & -0.123 & & \\
\hline & & $(1.031)$ & & \\
\hline \multirow[t]{2}{*}{ Communist Party } & & & 2.024 & \\
\hline & & & $(2.276)$ & \\
\hline \multirow[t]{2}{*}{ Communist Party Land } & & & -0.278 & \\
\hline & & & 2.940 & \\
\hline \multirow[t]{2}{*}{ Youth Union } & & & & -0.732 \\
\hline & & & & $(0.601)$ \\
\hline \multirow[t]{2}{*}{ Youth Union Land } & & & & 0.098 \\
\hline & & & & $(0.752)$ \\
\hline
\end{tabular}

Notes. ${ }^{*}$ and ${ }^{* *}$ mean for significance at the $10 \%$ and at the $5 \%$ level, respectively. $t$ statistics in parentheses, $\mathrm{n}=$ 240.

In addition, the results in Model B3 of Table 6 show that an increase 1\% in land and labor may lead to an increase $0.848 \%$ and $0.601 \%$ in tea income, respectively. The interac-tion between tea land and Communist Party also has a significantly negative effect (-0.278), implying a substitution effect between tea land and membership of the Communist Party. This finding is consistent with the results of Li et al. (2008), which showed that the negative coefficients of these interaction terms implies a power impact of becoming Party's member in the context of the stronger legal framework. The result is also consistent with the results of Boubakri et al. (2012) who found the negative effect of political ties on cost of firms' equity capital. 
Table 7. Restricted log likelihood

\begin{tabular}{lllll}
\hline Variable & Model B1 & Model B2 & Model B3 & Model B4 \\
\hline H0: $\theta=\lambda=-1$ & -401.82 & -402.95 & -403.56 & -402.66 \\
H0: $\theta=\lambda=0$ & 258.70 & 258.02 & 262.02 & 255.59 \\
& -303.85 & -305.08 & -304.83 & -305.24 \\
H0: $\theta=\lambda=1$ & 62.74 & 62.27 & 64.56 & 60.76 \\
& -273.01 & -274.53 & -273.29 & -275.26 \\
& 1.07 & 1.19 & 1.49 & 0.80
\end{tabular}

Notes. ${ }^{*}$ and ${ }^{* *}$ mean for significance at the $10 \%$ and at the $5 \%$ level, respectively.

\section{Conclusions}

The relation between households' income and land, labor, political connections has raised many puzzling issues that are interesting to researchers as well as policy makers. In this study, we focus on whether there exist an impact of political connections on farming households' performance, especially in tea production in Vietnam.

The findings indicate the significant role of political connection on improving farming households' income, particularly to members of the Youth Union and Farmer's Union. Surprisingly, the interaction effects of Farmer's Union/Youth Union and land on total income are negative. This could be explained that participating more on both Youth and Farmer's Union may reduce time invested in cultivating.

Similarly, the interactive coefficient between Veteran's Union/Communist Party and land on tea income are negative which implies that participating to both these organizations could lead to a decrease in cultivated land.

Interestingly, the results also reported that membership of these organizations a substitute of surface of tea land. This means that a reduction in tea land may be cooperated by political connection regarding household income. On the world, as developing tea land surface is difficult, if farmer wants to increase income, he/her should have a political connection (Farmer's Union, Youth Union, Veteran's Union and Communist Party)

\section{Acknowledgements}

We gratefully acknowledge the colleagues of economic department of the Vietnam National University of Agriculture in collecting data for this research. We gratefully acknowledge Dr. Phu Nguyen Van advices on the interpretations of some of our findings. We would like to thank Tran Thai Tan and Emre "Ozel for useful comments and suggestions. The findings, interpretations, and conclusions expressed in this paper are entirely those of the authors. All remaining errors are our own.

Help from colleagues of the economic department of the Vietnam National University of Agriculture in collecting data is gratefully acknowledged. We are grateful to Phu Nguyen Van for useful comments and suggestions. All remaining errors are our own.

\section{References}

Abrevaya, J. (2002). Computing marginal effects in the Box-Cox model. Econometric Reviews, 21, 383-393. http://dx.doi.org/10.1081/ETC-120015789

Adhikari, A., Derashid, C., \& Zhang, H. (2006). Public policy, political connections, and effective tax rates: Longitudinal evidence from Malaysia. Journal of Accounting and Public Policy, 25, 574-595. http://dx.doi.org/10.1016/j.jaccpubpol.2006.07.001

Amemiya, T., \& Powell, J. L. (1981). A comparison of the Box-Cox maximum likeli-hood estimator and the non-linear two-stage least squares estimator. Journal of Econo-Metrics, 17, 351-381. http://dx.doi.org/10.1016/0304-4076(81)90007-5

Amore, M. D., \& Bennedsen, M. (2013). The value of local political connections in a low-corruption $\begin{array}{lllll}\text { environment. Journal of Financial Economics, } & 110,\end{array}$ http://dx.doi.org/10.1016/j.jfineco.2013.06.002

Bardhan, P., \& Mookherjee, D. (2000). Capture and governance at local and national levels. American Economic Review, 90, 135-139. http://dx.doi.org/10.1257/aer.90.2.135

Battese, G. E. (1997). A note on the estimation of Cobb-Douglas production functions when some explanatory variables have zero values. Journal of Agricultural Economics, 48, 250-252. 
http://dx.doi.org/10.1111/j.1477-9552.1997.tb01149.x

Boubakri, N., Guedhami, O., Mishra, D., \& Saffar, W. (2012). Political connections and the cost of equity capital. Journal of Corporate Finance, 18, 541-559. http://dx.doi.org/10.1016/j.jcorpfin.2012.02.005

Box, G. E. P., \& Cox, D. R. (1964). An analysis of transformations. Journal of the Royal Statistical Society. Series $B, 26,211-252$.

Bunkanwanicha, P., \& Wiwattanakantang, Y. (2009). Big business owners in poli-tics. Review of Financial Studies, 22, 2133-2168. http://dx.doi.org/10.1093/rfs/hhn083

Caeyers, B., \& Dercon, S. (2012). Political connections and social networks in targeted transfer programs: Evidence from rural Ethiopia. Economic Development and Cultural Change, 60, 639-675. http://dx.doi.org/10.1086/665602

Charumilind, C. K. R., \& Wiwattanakantang, Y. (2006). Connected lending: Thai-land before the financial crisis. The Journal of Business, 79, 181-218. http://dx.doi.org/10.1086/497410

Chen, G., Firth, M., \& Xu, L. (2009). Does the type of ownership control matter? Evidence from China's listed companies. Journal of Banking and Finance, 33, 171-181. http://dx.doi.org/10.1016/j.jbankfin.2007.12.023

Cingano, F., \& Pinotti, P. (2013). Politicians at work: The private returns and social costs of political connections. Journal of the European Economic Association, 11, 433-465. http://dx.doi.org/10.1111/jeea.12001

Claessens, S., Feijen, E., \& Laeven, L. (2008). Political connections and preferential access to finance: The role of campaign contributions. Journal of Financial Economics, 88, 554-580. http://dx.doi.org/10.1016/j.jfineco.2006.11.003

Dalton, R. J., Hac, P. M., Nghi, P. T., \& Ong, N. N. T. (2002). Social relations and social capital in Vietnam: Findings from the 2002 World Values Survey. Comparative Sociology, 1, 369-386. http://dx.doi.org/10.1163/156913302100418646

Davidson, R., \& MacKinnon, J. G. (1985). Testing linear and loglinear regressions against Box-Cox alternatives. Canadian Journal of Economics, 18, 499-517. http://dx.doi.org/10.2307/135016

Deininger, K., \& Jin, S. (2008). Land sales and rental markets in transition: Evidence from rural Vietnam. Oxford Bulletin of Economics and Statistics, 70, 67-101.

Faccio, M. (2006). Politically connected firms. The American Economic Review, 96, $369-386$. http://dx.doi.org/10.1257/000282806776157704

Faccio, M., Masulis, R. W., \& McConnell, J. (2006). Political connections and corporate bailouts. The Journal of Finance, 61, 2597-2635. http://dx.doi.org/10.1111/j.1540-6261.2006.01000.x

Fan, J. P. H., Wong, T. J., \& Zhang, T. (2007). Politically connected CEOs, corpo-rate governance, and Post-IPO performance of China's newly partially privatized firms. Journal of Financial Economics, 84, 330-357. http://dx.doi.org/10.1016/j.jfineco.2006.03.008

Ferraz, C., \& Finan, F. (2008). Exposing corrupt politicians: The effects of Brazil's bublicly released audits on electoral outcomes. The Quarterly Journal of Economics, 123, 703-745. http://dx.doi.org/10.1162/qjec.2008.123.2.703

Finan, F., Sadoulet, E., \& De Janvry, A. (2005). Measuring the poverty reduction potential of land in rural Mexico. Journal of Development Economics, 77, 27-51. http://dx.doi.org/10.1016/j.jdeveco.2004.02.004

Firth, M., Rui, O. M., \& Wu, W. (2011). The effects of political connections and state ownership on corporate litigation in China. Journal of Law and Economics, 54, 573-607. http://dx.doi.org/10.1086/659261

Fisman, R. (2001). Estimating the value of political connections. American Economic Review, 91, $1095-1102$. http://dx.doi.org/10.1257/aer.91.4.1095

Goldman, E., Rocholl, J., \& So, J. (2009). Do politically connected boards affect firm value?" Review of Financial Studies, 22, 2331-2360. http://dx.doi.org/10.1093/rfs/hhn088

Gonzalez, M. A., \& Lopez, R. A. (2007). Political violence and farm household efficiency in Colombia. Economic Development and Cultural Change, 55, 367-392. http://dx.doi.org/10.1086/508715

Jayne, T. S., Yamano, T., Weber, M. T., Tschirley, D., Benfica, R., Chapoto, A., \& Zulu, B. (2003). Smallholder income and land distribution in Africa: Implications for poverty reduction strategies. Food Policy, 28, 253-275. http://dx.doi.org/10.1016/S0306-9192(03)00046-0 
Khwaja, A. I., \& Mian, A. (2005). Do lenders favor politically connected firms? Rent provision in an emerging financial market. The Quarterly Journal of Economics, 120, 1371-1411. http://dx.doi.org/10.1162/003355305775097524

Larochelle, C., \& Alwang, J. (2013). The role of risk mitigation in production effi-ciency: A case study of potato cultivation in the Bolivian Andes. Journal of Agricultural Economics, 64, 363-381. http://dx.doi.org/10.1111/j.1477-9552.2012.00367.x

Leuz, C., \& Oberholzer-Gee, F. (2006). Political relationships, global financing, and corporate transparency: Evidence from Indonesia. Journal of Financial Economics, 81, 411-439. http://dx.doi.org/10.1016/j.jfineco.2005.06.006

Li, H., Meng, L., Wang, Q., \& Zhou, L. A. (2008). Political connections, financing and firm performance: Evidence from Chinese private firms. Journal of Development Economics, 87, $283-299$. http://dx.doi.org/10.1016/j.jdeveco.2007.03.001

Markussen, T., \& Tarp, F. (2014). Political connections and land-related investment in rural Vietnam. Journal of Development Economics, 110, 291-302. http://dx.doi.org/10.1016/j.jdeveco.2014.01.011

Nguyen, C. V., \& Tran, A. N. (2014). The role of crop land during economic devel-opment: Evidence from rural Vietnam. European Review of Agricultural Economics, 41, 561-582. http://dx.doi.org/10.1093/erae/jbt032

Nguyen, C. V., Van den Berg, M., \& Lensink, R. (2011). The impact of work and non-work migration on household welfare, poverty and inequality. Economics of Transition, 19, 771-799. http://dx.doi.org/10.1111/j.1468-0351.2011.00416.x

Niessen, A., \& Ruenzi, S. (2010). Political connectedness and firm performance: Evi-dence from Germany. German Economic Review, 11, 441-464. http://dx.doi.org/10.1111/j.1468-0475.2009.00482.x

Onumah, E. E., Brummer, B., Horstgen-Schwark, G., et al. (2010). Productivity of hired and family labour and determinants of technical inefficiency in Ghana's fish farms. Agricultural Economics, 56, 79-88.

Poirier, D. J. (1978). The use of the Box-Cox transformation in limited dependent variable models. American Statistical Association, 73, 284-287. http://dx.doi.org/10.1080/01621459.1978.10481570

Rao, E. J. O., Brummer, B., \& Qaim, M. (2012). Farmer Participation in supermar-ket channels, production technology, and efficiency: The case of vegetables in Kenya. American Journal of Agricultural Economics, 94, 891-912. http://dx.doi.org/10.1093/ajae/aas024

Ravallion, M., \& Van de Walle, D. (2008). Land in Transition: Reform and Poverty in Rural Vietnam. World Bank Publications. http://dx.doi.org/10.1596/978-0-8213-7274-6

Sakia, R. M. (1992). The Box-Cox transformation technique: A review. The Statistician, 41, $169-178$. http://dx.doi.org/10.2307/2348250

Seaks, T. G., \& Layson, S. K. (1983). Box-Cox estimation with standard econometric problems. The Review of Economics and Statistics, 65, 160-164. http://dx.doi.org/10.2307/1924424

Spitzer, J. J. (1982). A primer on Box-Cox estimation. The Review of Economics and Statistics, 64, $307-313$. http://dx.doi.org/10.2307/1924310

Wooldridge, J. M. (1992). Some alternatives to the Box-Cox regression model. Inter-national Economic Review, 33, 935-955. http://dx.doi.org/10.2307/2527151

Wu, W., Wu, C., \& Rui, O. M. (2012). Ownership and the value of political connections: Evidence from China. European Financial Management, 18, 695-729. http://dx.doi.org/10.1111/j.1468-036X.2010.00547.x

\section{Notes}

Note 1. Box and Cox (1964) developed the transformation and argued that the transformation could make the residuals more closely normal and less heteroscedastic.

Note 2. Some studies applied a double-log function to model the relation between household earnings and land (see Ravallion \& Van de Walle, 2008). It is also used in other researches such as Jayne et al. (2003) and Finan et al. (2005), in which they dropped the variable of landless. In order to avoid dropping observed independent variables, some authors (e.g., Gonzalez \& Lopez, 2007; Deininger \& Jin, 2008; Onumah et al., 2010; Rao et al., 2012; Larochelle \& Alwang, 2013; Nguyen \& Tran, 2014, etc.) applied the method of Battese (1997). 


\section{Appendix}

Appendix 1. Definition of variables

\begin{tabular}{|c|c|c|}
\hline Variable name & Definition & Nature \\
\hline Land & land surface used in tea production (in $\mathrm{m}^{2}$ ) & continuous \\
\hline Labor & total labor employed (working-days) & continuous \\
\hline Total income & total income of household (million VND) & continuous \\
\hline Tea income & income of tea of household (million VND) & continuous \\
\hline Experience & number of years of the head of households & continuous \\
\hline Household size & number of members in the household & continuous \\
\hline Children & members of household less than 18 years old & continuous \\
\hline Elderly & members of household more than 60 years old & continuous \\
\hline Education & educational level of the head of households & continuous \\
\hline Gender & gender of the head of households (male $=1$, female $=0$ ) & dummy \\
\hline Veteran's Union & at least one of household' members participating this association & dummy \\
\hline Farmer's Union & at least one of household' members participating this association & dummy \\
\hline Communist Party & at least one of household' members participating this association & dummy \\
\hline Youth Union & at least one of household' members participating this association & dummy \\
\hline
\end{tabular}

\section{Copyrights}

Copyright for this article is retained by the author(s), with first publication rights granted to the journal.

This is an open-access article distributed under the terms and conditions of the Creative Commons Attribution license (http://creativecommons.org/licenses/by/3.0/). 